\title{
Characterisation of traditional Macedonian edible oils by their fatty acid composition and their volatile compounds
}

\author{
Violeta Ivanova-Petropulos ${ }^{a}$, Sasa Mitrev ${ }^{\text {a }}$, Trajce Stafilov $^{b}$, Natalija Markova ${ }^{\text {a }}$, Erich Leitner ${ }^{\text {, }}$, \\ Ernst Lankmayr ${ }^{\mathrm{c}}$, Barbara Siegmund ${ }^{\mathrm{c}, *}$ \\ a Faculty of Agriculture, University “Goce Delčev”, Štip, Krste Misirkov bb, 2000 Štip, Republic of Macedonia \\ b Institute of Chemistry, Faculty of Natural Sciences and Mathematics, Ss. "Cyril and Methodius" University, Arhimedova 5, 1000 Skopje, Republic of Macedonia \\ ${ }^{c}$ Institute of Analytical Chemistry and Food Chemistry, Graz University of Technology, NAWI Graz, Stremayrgasse 9/II, A8010 Graz, Austria
}

\section{A R T I C L E I N F O}

\section{Article history:}

Received 8 June 2015

Received in revised form 31 July 2015

Accepted 10 August 2015

Available online 12 August 2015

Keywords:

Traditional Macedonian edible oils

Fatty acids

Volatile compounds

Gas chromatography

\begin{abstract}
A B S T R A C T
The fatty acid composition and volatile compounds of selected traditional Macedonian edible oils of several varieties, including sunflower seeds, pumpkin seeds, flax seed, rapeseed and sesame seeds, were analysed. The fatty acid (FA) composition was determined by GC-FID analysis after transesterification into the corresponding methyl esters. $\alpha$-Linolenic acid (C18:3) was the main unsaturated fatty acid in flax seed oil ( $56.2 \%$ of total FA), oleic acid (C18:1) dominated in rapeseed and sesame seed oils (65.3 and 43\% of total FA, respectively), and linoleic acid (C18:2) was the dominant compound in sunflower and pumpkin seed oils (59.2 and 59.5\% of total $\mathrm{FA}$, respectively). The volatile flavour compounds were determined using headspace solid phase microextraction (HS-SPME) using a DVB/Carboxen/PDMS fibre, coupled with gas chromatography-mass spectrometry (GC-MS). In total 97 volatile compounds were detected revealing a very complex aroma profile of the oils, composed of acids, alcohols, aldehydes, alkanes, alkenes, esters, furans, pyrazines, sulphur compounds and terpenes. Among them, aldehydes presented the highest proportion of the overall volatiles in rapeseed oil ( $76.8 \%$ of the total volatiles), followed by sesame seed oil ( $25 \%$ of the total volatiles), pumpkin seed (5.45\% of the total volatiles), flax seed oil ( $2.5 \%$ of the total volatiles) and sunflower seed oil ( $0.95 \%$ of the total volatiles). Terpenes (41 detected) were the dominant compounds in sunflower seed oil and pumpkin seed oil ( 93.9 and $87.8 \%$ of the total terpenes, respectively), followed by flax seed oil ( $47.6 \%$ of the total terpenes), sesame seed oil ( $21.5 \%$ of the total terpenes) and rapeseed oil ( $10 \%$ of total the terpenes). Sunflower seed and pumpkin seed oil showed the highest number of volatile compounds identified, with the highest number of terpenes and esters within the investigated products.
\end{abstract}

(c) 2015 Elsevier Ltd. All rights reserved.

\section{Introduction}

Edible oils are recognized as essential nutrients in both human and animal diets. From a nutrition point of view, they are concentrated sources of energy providing essential fatty acids which are considered as building blocks for hormones, as well as a carrier medium for the oil soluble vitamins A, D, E, and K (Tannenbaum, 1979). Different classes of compounds are present in edible oils, such as fatty acids, tocopherols, phenolic compounds, phytosterols, carotenoids and thioglycosides (Gromadzka \& Wardencki, 2011).

The fatty acid composition varies significantly within oils from different plant sources, predominantly depending on the variety, but also on the state of ripeness, the area in which the plants are grown, climate conditions etc. (Murkovic, Hillebrand, Winkler, Leitner \& Pfannhauser, 1996;

\footnotetext{
* Corresponding author at: Institute of Analytical Chemistry and Food Chemistry, Graz University of Technology, Graz, Stremayrgasse 9/II, A8010 Graz, Austria.

E-mail address: barbara.siegmund@tugraz.at (B. Siegmund).
}

Schuster, Zipse \& Marquard, 1983). In general, fatty acids are classified according to their degree of saturation: saturated or unsaturated with one double bond (mono-unsaturated) or more than one double bond (poly-unsaturated). The major unsaturated fatty acids are oleic acid $(\mathrm{OA})$, linoleic acid (LA) and $\alpha$-linolenic acid (ALA). Fatty acids with even numbers of carbon atoms, from 16 to 18 , with a single carboxyl group, are the most common fatty acids present in vegetable oils (Ballesteros, Gallego \& Valcárcel, 1993; De Koning, van der Meer, Alkema, Janssen \& Brinkman, 2001).

Unsaturated fatty acids tend to oxidize in the presence of radicals, oxygen, metal catalysts or lipoxygenase enzymes, producing volatile organic compounds (VOCs). VOCs have low molecular weights (usually less than $300 \mathrm{Da}$ ), which are easily vaporized at room temperature and which may produce an odour sensation (Temime, Campeol, Cioni, Daoud \& Zarrouk, 2006). These compounds may have positive or negative (off-flavour) impact on the flavour of the oil. The presence/absence of VOCs in different proportions can be taken as a marker for identifying adulteration. Important flavour compounds of oils are mainly produced by the endogenous plant 
enzymes as a result of the lipoxygenase pathway. Further volatile and odour-active compounds are formed during the chemical oxidation (autoxidation) of lipids (Wilkes et al., 2000). These compounds contribute significantly to the flavour of the freshly pressed oils. During storage, autoxidation of edible oils continues whereas at some point - depending on the concentration of the volatile and odouractive autoxidation products - the desired flavour turns into offflavour in terms of rancidity. How quickly the flavour of edible oils turns into off-flavour depends on various factors, like for example the fatty acid composition, storage conditions, influence of UV light or the presence of metal ions (Choe \& Min, 2006; Jansen, 2015). Off-flavour of edible oils may also be caused by the presence of exogenous enzymes. Moreover, the flavour compounds in edible oils can be formed from amino acids such as valine and leucine, which can be converted into volatile compounds, such as esters and alcohols which may, as a consequence, also influence the sensory perception of edible oils such as olive oils (Kalua et al., 2007).

Since the chemical composition of edible oils is very complex, different analytical methods have been proposed to isolate, identify and quantify different compounds that characterise oils. Highperformance liquid chromatography (HPLC) connected to different detection systems was successfully used for the identification and quantification of fatty acids, triacylglycerols, sterols, tocopherols and hydrocarbons (Cao et al., 2014; Gliszczyńska-Świgło, Sikorska, Khmelinskii \& Sikorski, 2007; Murkovic, Piironen, Lampi, Kraushofer \& Sontag, 2004; Zeb \& Murkovic, 2010). Furthermore, gas chromatography (GC) is the technique of choice for the analysis of fatty acids, usually coupled with a flameionization detector (FID) or for the analysis of volatile compounds (Haiyan, Bedgood, Bishop, Prenzler \& Robards, 2007; Murkovic et al., 1996). GC or HPLC in combination with mass spectrometry, as sophisticated techniques allowing structural identification and quantification by single-ion monitoring (SIM) or multiple-ion monitoring (MIM) of different classes of compounds, are used for the analysis of different classes of compounds present in the oils (Haiyan et al., 2007; Ma et al., 2014; Zhang et al., 2014). Recently, a headspace comprehensive two-dimensional gas chromatography time-of-flight mass spectrometry (Headspace GC $\times$ GC-TOF/ MS) was used for the classification of volatiles from vegetable oils in order to build a statistical model that should help to identify adulteration of oils (Hu et al., 2014).

Even though vegetable oils from several plant species have traditionally been produced in Macedonia, there are only very few studies dealing with the properties of these products. Few studies focusing on the chemical composition of essential oils from various plant and herb species grown in Republic of Macedonia, such as Salvia officinalis populations, have been performed (Kostadinova et al., 2007; Najdoska, Bogdanov \& Zdravkovski, 2010; Stefkov, Cvetkovikj, Karapandzova \& Kulevanova, 2011). Only a preliminary study about fatty acid composition of vegetable oils and fats (Kostik, Memeti \& Bauer, 2013) as well as one study concerning on antioxidative capacity determined by a voltammetric method (Gulaboski, Mirceski \& Mitrev, 2013) are available in literature. However, detailed knowledge about the properties of these traditional oils is required in order to further improve their quality.

To the best of our knowledge, there has been no report on the identification and quantification of individual flavour compounds of Macedonian edible oils from different cultivars. Concerning this, the objectives of the present work were twofold: (1) characterisation of the fatty acids and the volatile compounds of the local edible oils and (2) correlation of the data in order to receive a useful data set for the oil producing industry in the country. Automated headspace solidphase microextraction coupled with gas chromatography-mass spectrometry (HS-SPME GC-MS) was used for the analysis of the volatile compounds, and gas chromatography coupled with a flame ionization detector (GC-FID) was used for the analysis of the fatty acid after transesterification of the glycerides into the corresponding fatty acid methyl esters.

\section{Materials and methods}

\subsection{Chemicals and reagents}

The reference materials (fatty acid methyl esters) were purchased from Nu-Chek Prep, (Elysian, Minnesota, USA). The boron trifluoridemethanol complex ( $\mathrm{BF}_{3}$ solution $20 \%$ in methanol), which was used for derivatisation of the fatty acids, was purchased from Merck (Darmstadt, Germany). All chemicals and solvents used (e.g. hexane, heptane) were of analytical grade and were purchased from Merck (Darmstadt, Germany).

\subsection{Oil samples}

Five oil samples from different seed varieties (sunflower seeds, pumpkin seeds, flax seeds, rapeseeds and sesame seeds) were produced in 2014, in an oil factory located in the eastern part of the Republic of Macedonia. Prior to the production of the oils, the seeds from sunflower, flax, rape and sesame, were preconditioned by heating to temperatures between $40-50{ }^{\circ} \mathrm{C}$ before pressing. Only pumpkin seeds were heated to temperatures of $90-100{ }^{\circ} \mathrm{C}$. Pressing of the seeds was performed by using a single press of a capacity of $20-25 \mathrm{~kg} \mathrm{~h}^{-1}$. The press was equipped with an electric motor of an electric capacity of $1.5 \mathrm{~kW}$. After pressing, the oils were stabilized for a period of 1 to 2 months, afterwards filtered and bottled. All oils were produced in three lots (in triplicates). To obtain the final oil, equal portions of each lot were blended. For the purpose of this study, samples were collected out of the final blends in $15 \mathrm{~mL}$ plastic tubes and purged with nitrogen in order to avoid oxidation. In order to protect the oils from UV light, the tubes were covered with aluminum foil, packed in a box with dried ice and transported to the laboratory for analysis. To keep oxidation as low as possible, the oil samples were stored in a refrigerator $\left(4^{\circ} \mathrm{C}\right)$ until use.

\subsection{Fatty acid derivatisation and GC-FID analysis}

The previously described transesterification method was used to transform the fatty acid glycerides into the corresponding methyl esters (Murkovic et al., 1996) Transesterification was performed by the use of boron trifluoride methanol complex $\left(20 \% \mathrm{BF}_{3}\right.$ in methanol). $\mathrm{BF}_{3^{-}}$ methanol is one of the fastest and most convenient ways to convert fatty acids to their methyl ester derivatives. Thus, approximately $20 \mathrm{mg}$ of an oil sample was transferred into a screw-cap test tube ( $30 \mathrm{~mL}$ ) and $1 \mathrm{~mL}$ of a solution containing $1 \mathrm{~g} \mathrm{~L}^{-1}$ of pentadecanoic acid (C15:0 in methanol) was added as internal standard (IS). The mixture was reduced to dryness under nitrogen flow $\left(\mathrm{N}_{2}\right)$ and the residue was redissolved in $6 \mathrm{~mL}$ of $0.5 \mathrm{M}$ methanolic $\mathrm{NaOH}$ solution. The tube was capped and stirred on a magnetic stirrer while heating to $80^{\circ} \mathrm{C}$ for $30 \mathrm{~min}$. After that, the tube was cooled to room temperature and $6 \mathrm{~mL} \mathrm{BF}_{3}$-methanol solution was added to the sample. The sample was stirred again on a magnetic stirrer at $80{ }^{\circ} \mathrm{C}$ for $15 \mathrm{~min}$. After cooling down to room temperature, $10 \mathrm{~mL} \mathrm{H}_{2} \mathrm{O}$ and $10 \mathrm{~mL}$ heptane were added to the samples, followed by stirring on a magnetic stirrer for $10 \mathrm{~min}$ and subsequent vortexing for 1-2 min. Aliquots of the methylated samples were placed into an autosampler and analysed with GC-FID. Each oil sample was transesterified and analysed in four replicates. GCFID analyses were performed on a gas chromatograph (Hewlett Packard 5890 series II, Wilmington, DE, USA) equipped with a split/splitless injector (split ratio of 1:30) and a flame ionization detector (FID), using an HP Innowax (30 $\mathrm{m} \times 0.32 \mathrm{~mm}$ I.D.) capillary column with a film thickness of $0.25 \mu \mathrm{m}$. The temperature programme for the separation of the fatty acid methyl esters was as follows: $1 \mathrm{~min}$ isothermal at $50{ }^{\circ} \mathrm{C}, 8{ }^{\circ} \mathrm{C} \min ^{-1}$ to $140{ }^{\circ} \mathrm{C}$ followed by a temperature ramp of 
$8^{\circ} \mathrm{C} \mathrm{min}^{-1}$ to $240{ }^{\circ} \mathrm{C}(10 \mathrm{~min})$. The sample volume injected was $1 \mu \mathrm{l}$. The injector temperature was $220^{\circ} \mathrm{C}$ and the temperature of the detector was $260^{\circ} \mathrm{C}$. Helium (purity $\geq 99.999 \%$ ) was used as a carrier gas at a constant pressure of $70 \mathrm{kPa}$. The data processing was performed with the Chemstation software running under Windows (Microsoft). The compounds were identified using a reference mixture of fatty acids methyl esters (FAME). The amount of fatty acids was expressed as the percentage of the fatty acids of interest.

\subsection{HS-SPME-GC-MS analysis of flavour compounds}

An automated headspace solid-phase microextraction (HSSPME) system combined with gas chromatography-mass spectrometry (GC-MS) was used for extraction, enrichment and subsequent separation of the volatile compounds from the investigated oil samples. For the HS-SPME, about $100 \mathrm{mg}$ of oil was transferred into a $20 \mathrm{~mL}$ headspace vial. Before closing the vial, the headspace was flushed with nitrogen to prevent autoxidation of the sample. The following SPME fibre was used: Divinylbenzene/Carboxen/Polydimethylsiloxane (DVB/Carboxen/PDMS) 50/30 $\mu \mathrm{m}, 2 \mathrm{~cm}$ stable flex (Supelco, Bellfonte, USA). Sampling was performed using a CTC Combi PAL sampler (CTC Analytics, Switzerland). Prior to the extraction of the volatiles, the samples were equilibrated in the oven of the autosampler at $60{ }^{\circ} \mathrm{C}$ for $5 \mathrm{~min}$. In the oven, the samples were stirred thoroughly using a glass coated magnetic stirrer. The SPME fibre was exposed into the headspace of the sample for $10 \mathrm{~min}$ at $60{ }^{\circ} \mathrm{C}$. Immediately after the exposure, the fibre was transferred to the GCinjector for thermo-desorption at $270{ }^{\circ} \mathrm{C}$. The SPME fibre was left in the injection port for re-conditioning ( $20 \mathrm{~min}$ ) before it was exposed to the headspace of the next sample.

GC-MS analysis were performed on an Agilent system (GC 7890, MS 5975c VL MSD, Santa Clara, CA, USA) using an analytical column of medium polarity (HP5MS, $30 \mathrm{~m}^{*} 0.25 \mathrm{~mm}^{*} 1 \mu \mathrm{m}$, Agilent Technologies) with the following temperature programme: $-10{ }^{\circ} \mathrm{C}$ for $1 \mathrm{~min}$ with a temperature ramp of $12{ }^{\circ} \mathrm{C} \mathrm{min}-1$ up to $280{ }^{\circ} \mathrm{C}$ (holding time $3 \mathrm{~min}$ ). Cryo-focussing by blowing liquid nitrogen into the GC-oven was applied to reach the start temperature of $-10{ }^{\circ} \mathrm{C}$ with the aim to obtain higher resolution for compounds with very high volatility. The mass selective detection was performed in the scan mode (20-300 amu, EI (70 eV), detector temperature $230{ }^{\circ} \mathrm{C}$ ).

Identification of the volatile compounds was performed by probability based matching of the obtained mass spectra with the mass spectra from the NIST library as well as from literature. As a second criterion for the identification, linear temperature programmed retention indices (RI) were calculated according to Farkaš, Le Quéré, Maarse \& Kovać (1994). Measured RIs were compared to data obtained from authentic reference compounds or from retention index databases (www. flavornet.org, webbook.nist.gov/chemistry, www.pherobase.com). Compounds are marked as 'tentatively identified' when no authentic reference compounds were available (Table 2). Relative amounts of the volatile compounds were calculated in terms of area counts from fourfold HS-SPME GC-MS measurements.

\subsection{Statistical analysis}

Each oil sample was analysed in four replicates. Results were statistically treated by calculation of means, standard deviations and relative standard deviations. In addition, the ANOVA test of Student-NewmanKeuls of multiple comparisons of mean values was applied to the results to ascertain possible significant differences in the result for each aroma compound between the investigated oils using GraphPad InStat Software (Version 3.05, USA). Differences were considered to be statistically significant at the level of $p<0.05$. In order to reveal any grouping of the oil samples based on the composition of volatile compounds and fatty acid composition, as well as to identify the constituents that are the chemotypical factors, the samples were analysed using principal component analysis (PCA) with the software package TANAGRA 1.4.28 (Lyon, France).

\section{Results and discussion}

\subsection{Fatty acid composition}

The fatty acid (FA) composition of the investigated oils was calculated in terms of percentage of the investigated saturated and unsaturated fatty acids with chain lengths from C14 to C18 (Table 1).

Six different types of fatty acids were found in the investigated oils samples. Palmitic acid (C16:0) and stearic acid (C18:0) were common in all oils. Oleic acid (C18:1), linoleic acid (C18:2) and $\alpha$-linolenic acid (C18:3) were dominant within the unsaturated FAs of all oils. Myristic acid (C14:0) was present only in the sunflower seed and pumpkin seed oil in low amounts, while myristoleic acid (C14:1) could not be detected in any sample.

Unsaturated fatty acids were the dominant fatty acids in the oils ranging from $84.4 \%$ to $93.2 \%$, in accordance to previously published data (Haiyan et al., 2007). On average, rapeseed oil contained the highest percentage of unsaturated acids (93.2\%), followed by flax seed (89.7\%), sesame seed (88.9\%), sunflower seed $(88.4 \%)$ and pumpkin seed oil (84.4\%). In terms of variety, $\alpha$-linolenic acid (C18:3) was the main unsaturated FA in flax seed oil ( $56.2 \%$ of the total FA), oleic acid (C18:1) dominated in rapeseed and sesame seed oils (65.3\% and 43\% of the total FA, respectively) and linoleic acid (C18:2) was the dominant compound in sunflower seed and pumpkin seed oil (59.2\% and 59.5\% of the total FA, respectively). Sunflower seed oil as well as pumpkin seed oil contained the saturated myristic acid (C14:0) in same percentage ( $0.07 \%$ of the total FA), whereas myristic acid could not be identified in any of the other investigated oil samples. Generally, the oils in this study showed fatty acid profiles in accordance to the data published in the Official Gazzete of the Republic of Macedonia and No. 127 (2012). Additionally, the results were consistent with the fatty acid profiles data published by other groups previously (Haiyan et al., 2007; Kostik et al., 2013).

The dataset of the relative contents of each fatty acid determined by GC-FID was processed applying principal component analysis (PCA) to explore clustering among the oils and the corresponding fatty acid distribution. The first two principal components, PC1 and PC2, accounted for $82.2 \%$ of the total variance (48.39\% for PC1 and $33.82 \%$ for PC2), thus explaining significant information within the dataset. The projection of the oils on the first two principal components showed a separation according to the variety (Fig. 1a): rapeseed oil was located in the upper negative part of PC1 and flax seed oil in the upper positive part of PCA-biplot, while the sunflower seed, pumpkin seed and sesame oils were located on the left side of PC1, forming a group.

The PCA results of the variables (fatty acids) used for characterisation of the oil samples displayed in terms of the first two principal components are presented in Fig. 1b. It can be noticed that unsaturated acids (C16:1, C18:1 and C18:3) are characteristic for flax seed oil and rapeseed oil. They prevail in the positive part of the first principal component. Flax seed oil located in the upper right quarter is richest in C18:3, while rapeseed oil presents highest content of C16:1 and C18:1. Saturated acids (C14:0, C16:0 and C18:0) prevail in the negative part of PC1, together with $\mathrm{C} 18: 2$. The fatty acid $\mathrm{C} 18: 2$ was dominant in the sesame seed, sunflower seed and pumpkin seed oils, which are grouped and separated from the flax seed oil and rapeseed oil.

\subsection{Volatile compounds - 'Aroma profile'}

The aroma profiles of the edible oils produced from sunflower seeds, pumpkin seeds, flax seeds, rapeseed and sesame seeds were determined by the use of HS-SPME GC-MS as described above. In this study, a total of 97 individual volatile compounds were identified and reported for the first time here in Macedonian oil samples. Different 
Table 1

Fatty acid composition of different oil samples (flax seed, rapeseed, sesame seed, sunflower seed and pumpkin seed oils).

\begin{tabular}{|c|c|c|c|c|c|}
\hline \multirow[t]{2}{*}{ Fatty acids (\%) } & \multicolumn{5}{|l|}{ Oil samples } \\
\hline & Flax seed & Rapeseed & Sesame seed & Sunflower seed & Pumpkin seed \\
\hline C14:0 & n.d. & n.d. & n.d. & $0.07 \pm 12.8$ & $0.07 \pm 8.65$ \\
\hline $\mathrm{C} 14: 1$ & n.d. & n.d. & n.d. & n.d. & n.d. \\
\hline C16:0 & $5.70 \pm 2.16$ & $5.15 \pm 11.6$ & $10.2 \pm 12.1$ & $7.31 \pm 11.7$ & $7.79 \pm 1.93$ \\
\hline C16:1 & $0.07 \pm 14.3$ & $0.22 \pm 0.001$ & $0.09 \pm 7.78$ & $0.09 \pm 0.001$ & $0.09 \pm 0.001$ \\
\hline C18:0 & $4.61 \pm 2.27$ & $1.66 \pm 13.2$ & $5.42 \pm 12.6$ & $3.75 \pm 8.00$ & $3.78 \pm 3.70$ \\
\hline C18:1 & $17.8 \pm 1.60$ & $65.3 \pm 0.77$ & $43.0 \pm 13.7$ & $29.5 \pm 1.70$ & $28.7 \pm 2.48$ \\
\hline C18:2 & $15.6 \pm 0.79$ & $19.8 \pm 13.1$ & $41.1 \pm 11.8$ & $59.2 \pm 6.74$ & $59.5 \pm 2.72$ \\
\hline C18:3 & $56.2 \pm 1.15$ & $7.86 \pm 0.38$ & $0.14 \pm 13.4$ & $0.07 \pm 11.8$ & $0.09 \pm 0.001$ \\
\hline Saturated & $10.3 \pm 12.4$ & $6.81 \pm 8.30$ & $15.5 \pm 13.3$ & $11.1 \pm 12.4$ & $15.6 \pm 1.88$ \\
\hline Unsaturated & $89.7 \pm 4.86$ & $93.2 \pm 2.85$ & $83.9 \pm 12.0$ & $88.8 \pm 4.85$ & $84.4 \pm 1.04$ \\
\hline
\end{tabular}

Abbreviation of fatty acids: C14:0 = myristic; $\mathrm{C} 14: 1=$ myristoleic; $\mathrm{C} 16: 0=$ palmitic; $\mathrm{C} 16: 1=$ palmitoleic; $\mathrm{C} 18: 0=$ stearic; $\mathrm{C} 18: 1=$ oleic; $\mathrm{C} 18: 2=$ linoleic; $\mathrm{C} 18: 3=\alpha-$ linolenic.

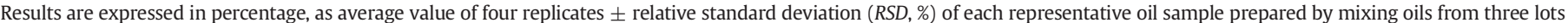
prepared at same way.

n.d.-not detected.

families of volatile compounds were considered: acids, alcohols, aldehydes, alkanes, alkenes, esters, furans, pyrazines, sulphur compounds, terpenes and other compounds. The compounds identified in the investigated oils are presented in Table 2.

\subsubsection{Acids}

Within the group of acids, acetic acid was the only identified volatile compound, present in highest relative amount in pumpkin seed oil, followed by sesame seed oil, sunflower seed and rapeseed oil. The presence of acetic acid was expected since it is a common volatile compound in oils which is formed in course of the processing of the seeds (Santos, Villarino, Zosa \& Dayrit, 2011).

\subsubsection{Alcohols}

Aliphatic alcohols are important compounds for the characterisation of edible oils. It is well known that their content and composition can vary widely between different oils in comparison to the fatty acid composition (Cert, Moreda \& Perez-Camino, 2000). In this study, the alcohols presented the highest proportion in flax seed oil ( $40.6 \%$ of the total volatiles) and sesame seed oil (33.1\% of the total volatiles), followed by rapeseed oil ( $6.4 \%$ of the total volatiles), pumpkin seed oil $(2.25 \%$ of the total volatiles) and sunflower seed oil ( $0.71 \%$ of the total volatiles). Comparing the relative content of the total alcohols, flax seed oil showed the highest relative amount, followed by pumpkin seed oil $(p>0.05)$. In total, 12 individual alcohols were identified (Table 2) and among them, 1-hexanol was the dominant compound from this fraction in flax seed oil ( $48.8 \%$ of the total alcohols), rapeseed and sesame seed oil (29.6\% of the total alcohols, in both oils). Furthermore, considerable amounts of ethanol were detected in sunflower seed and sesame seed oil (35.5\% and $25.4 \%$ of the total alcohols, respectively).

\subsubsection{Aldehydes}

Aldehydes are common volatile compounds in vegetable oils produced as a result of oxidation processes of fatty acids. The lipoxygenase (LOX) pathway upon cell disruption of the oilseeds (Feussner \& Wasternak, 2002) on the one hand as well as autoxidation reactions during processing and storage on the other hand are the two main formation pathways for aldehydes in edible oils. This group represented the highest proportion of overall volatiles in rapeseed oil ( $76.8 \%$ of the total volatiles), followed by sesame seed oil (25\% of the total volatiles), whereas pumpkin seed oil (5.45\% of the total volatiles), flax seed oil (2.5\% of the total volatiles) and sunflower seed oil ( $0.95 \%$ of the total volatiles) showed significantly lower amounts of aldehydes among the volatile compounds. Within this family, 13 aldehydes were identified in the oils. Hexanal was the main aldehyde in four oils samples, with a percentage of $70.8 \%$ of the total aldehydes in sunflower seed oil, $64.9 \%$ of the total aldehydes in sesame seed oil, $45.8 \%$ of the total aldehydes in pumpkin seed oil and $44.6 \%$ of the total aldehydes in rapeseed oil. 2-Methyl butanal and 2-hexanal (E) prevailed in flax seed oil (46\% and $38.4 \%$ of the total aldehydes, respectively). Nonanal was detected
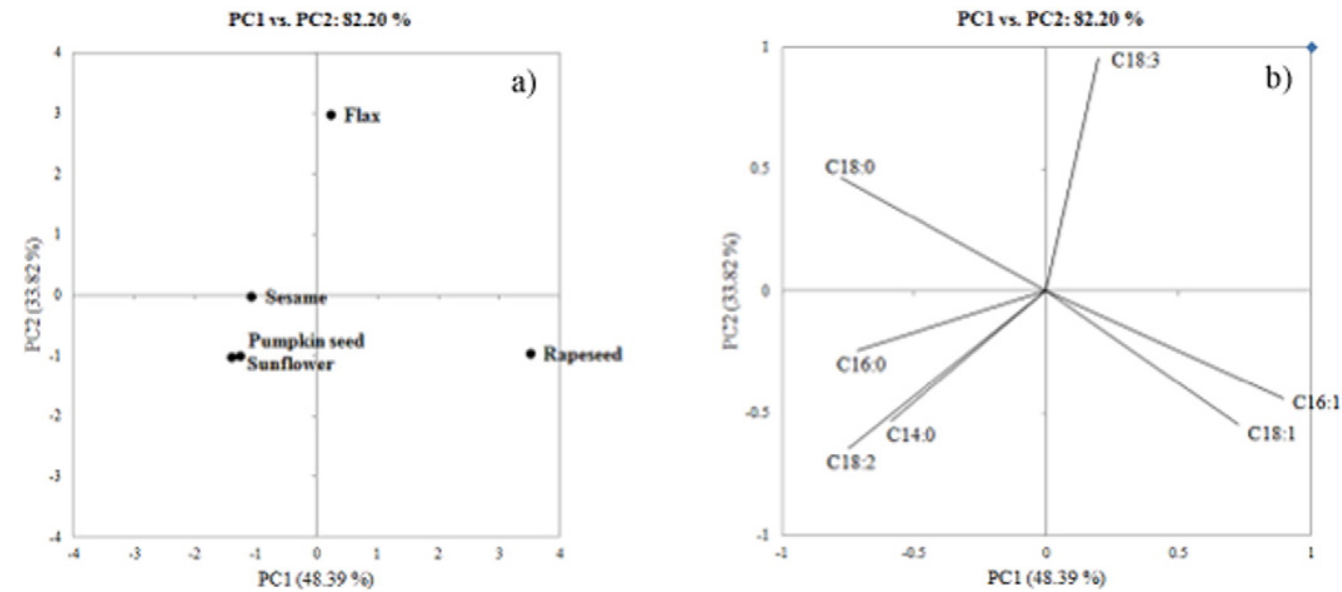

Fig. 1. Classification of the investigated oil samples analysed in function of PC1 and PC2, for the analysed fatty acids (a). PCA loadings of all analysed fatty acids in oil samples (b). 
Table 2

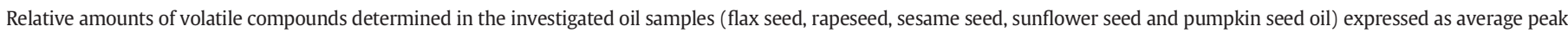
areas $(n=4)$.

\begin{tabular}{|c|c|c|c|c|c|c|c|}
\hline $\begin{array}{l}\text { Volatiles/samples } \\
\text { [peak area counts] }\end{array}$ & $\begin{array}{l}\mathrm{RI}_{\text {exp. }} \\
\text { [HP5] }\end{array}$ & $\begin{array}{l}\mathrm{RI}_{\mathrm{ref}} \\
{[\mathrm{HP5}]}\end{array}$ & $\begin{array}{l}\text { Flax seed } \\
\text { oil } \pm \text { RSD (\%) }\end{array}$ & $\begin{array}{l}\text { Rapeseed } \\
\text { oil } \pm \text { RSD (\%) }\end{array}$ & $\begin{array}{l}\text { Sesame seed } \\
\text { oil } \pm \text { RSD (\%) }\end{array}$ & $\begin{array}{l}\text { Sunflower seed } \\
\text { oil } \pm \text { RSD }(\%)\end{array}$ & $\begin{array}{l}\text { Pumpkin seed } \\
\text { oil } \pm \text { RSD (\%) }\end{array}$ \\
\hline $\begin{array}{l}\text { Acids } \\
\text { Acetic acid } \\
\text { Total acids }\end{array}$ & 601.3 & $600^{\mathrm{d}}$ & $\begin{array}{l}\text { n.d. } \\
\text { n.d. }\end{array}$ & $\begin{array}{l}756,071 \pm 4.01 \\
756,071^{\mathrm{a}} \pm 4.01\end{array}$ & $\begin{array}{l}3,423,859 \pm 9.99 \\
3,423,859^{\mathrm{a}} \pm 9.99\end{array}$ & $\begin{array}{l}1,215,841 \pm 5.80 \\
1,215,841^{\mathrm{a}} \pm 5.80\end{array}$ & $\begin{array}{l}46,977,316 \pm 5.80 \\
46,977,316 \pm 5.80\end{array}$ \\
\hline $\begin{array}{l}\text { Alcohols } \\
\text { Ethanol }^{\mathrm{t}} \\
\text { 2-Propanol } \\
\text { 2-Butanol } \\
\text { 2-Methyl-3-buten-2-ol } \\
\text { 2-Methyl-1-propanol } \\
\text { 1-Penten-3-ol } \\
\text { 3-Methyl-1-butanol } \\
\text { 2-Methyl-1-butanol } \\
\text { 1-Pentanol } \\
\text { 2,3-Butanediol } \\
\text { 1,3-Butanediol } \\
\text { 1-Hexanol } \\
\text { Total alcohols }^{\mathrm{t}}\end{array}$ & $\begin{aligned}<600 \\
<600 \\
600.3 \\
612.7 \\
630.5 \\
685.4 \\
736.7 \\
740.5 \\
767.8 \\
778.8 \\
788.1 \\
867.8\end{aligned}$ & $\begin{array}{l}537^{\mathrm{f}} \\
526^{\mathrm{e}} \\
600^{\mathrm{c}} \\
611^{\mathrm{e}} \\
678^{\mathrm{c}} \\
736^{\mathrm{d}} \\
739^{\mathrm{d}} \\
762.5^{\mathrm{c}} \\
789^{\mathrm{e}} \\
782-815^{\mathrm{e}} \\
866.5^{\mathrm{c}}\end{array}$ & $\begin{array}{l}5,773,686 \pm 10.9 \\
2,033,324 \pm 10.8 \\
5,840,071 \pm 8.49 \\
437,618 \pm 6.54 \\
3,900,601 \pm 3.23 \\
4,012,281 \pm 2.57 \\
5,876,512 \pm 2.01 \\
5,861,132 \pm 3.29 \\
8,018,007 \pm 2.13 \\
1,172,513 \pm 10.9 \\
899,642 \pm 7.15 \\
42,193,653 \pm 5.00 \\
86,019,040 \pm 6.08\end{array}$ & $\begin{array}{l}3,321,527 \pm 8.95 \\
\text { n.d. } \\
\text { n.d. } \\
\text { n.d. } \\
962,979 \pm 5.82 \\
2,064,505 \pm 3.14 \\
535,132 \pm 11.1 \\
701,238 \pm 4.95 \\
1,249,543 \pm 1.01 \\
970,748 \pm 4.26 \\
932,887 \pm 1.42 \\
4,519,376 \pm 8.85 \\
15,257,936^{a} \pm 5.50\end{array}$ & $\begin{array}{l}5,537,223 \pm 6.06 \\
\text { n.d. } \\
\text { n.d. } \\
\text { n.d. } \\
517,346 \pm 5.29 \\
\text { n.d. } \\
1,113,518 \pm 7.22 \\
1,036,867 \pm 6.70 \\
2,630,655 \pm 1.16 \\
1,610,062 \pm 7.45 \\
2,906,660 \pm 7.13 \\
6,467,653 \pm 2.45 \\
21,819,984^{a} \pm 5.43\end{array}$ & $\begin{array}{l}5,855,794 \pm 8.37 \\
1,827,241 \pm 6.54 \\
\text { n.d. } \\
\text { n.d. } \\
779,532 \pm 9.20 \\
\text { n.d. } \\
1,470,557 \pm 4.85 \\
1,856,677 \pm 2.95 \\
994,113 \pm 5.19 \\
\text { n.d. } \\
1,031,013 \pm 6.51 \\
2,696,261 \pm 2.57 \\
16,511,188^{a} \pm 5.77\end{array}$ & $\begin{array}{l}2,978,978 \pm 10.0 \\
\text { n.d. } \\
\text { n.d. } \\
\text { n.d. } \\
\text { n.d. } \\
\text { n.d. } \\
\text { n.d. } \\
\text { n.d. } \\
2,640,444 \pm 7.60 \\
14,367,143 \pm 6.04 \\
20,468,366 \pm 4.46 \\
2,887,643 \pm 2.72 \\
43,342,574 \pm 6.16\end{array}$ \\
\hline $\begin{array}{l}\text { Aldehydes } \\
\text { Propanal }^{\mathrm{t}} \\
\text { 2-Methyl-propanal } \\
\text { Butanal }^{\mathrm{t}} \\
\text { (E) 2-Butenal } \\
\text { 3-Methyl-butanal } \\
\text { 2-Methyl-butanal } \\
\text { Pentanal } \\
\text { Hexanal } \\
\text { (E) 2-Hexenal } \\
\text { (E) 2-Heptenal } \\
\text { Benzaldehyde } \\
\text { Octanal } \\
\text { Nonanal } \\
\text { Total aldehydes }\end{array}$ & $\begin{array}{r}<600 \\
<600 \\
<600 \\
655.8 \\
658.5 \\
668.2 \\
700.0 \\
801.3 \\
856.8 \\
960.8 \\
974.7 \\
1006.1 \\
1108.0\end{array}$ & $\begin{array}{l}494.5^{\mathrm{c}} \\
552^{\mathrm{e}} \\
596^{\mathrm{d}} \\
657^{\mathrm{e}} \\
647.5^{\mathrm{c}} \\
658^{\mathrm{c}} \\
697^{\mathrm{c}} \\
800^{\mathrm{c}} \\
850^{\mathrm{c}} \\
955^{\mathrm{c}} \\
958^{\mathrm{c}} \\
1003^{\mathrm{c}} \\
1105^{\mathrm{c}}\end{array}$ & $\begin{array}{l}\text { n.d. } \\
\text { n.d. } \\
129,242 \pm 9.20 \\
\text { n.d. } \\
703,115 \pm 4.80 \\
2,450,695 \pm 1.91 \\
\text { n.d. } \\
\text { n.d. } \\
\text { 2,044,259 } \pm 6.78 \\
\text { n.d. } \\
\text { n.d. } \\
\text { n.d. } \\
\text { n.d. } \\
\text { 5,327,311 } \pm 5.67\end{array}$ & $\begin{array}{l}3,723,583 \pm 4.69 \\
478,304 \pm 3.64 \\
830,720 \pm 1.85 \\
310,757 \pm 8.10 \\
3,750,464 \pm 1.16 \\
2,533,403 \pm 4.79 \\
6,445,551 \pm 3.01 \\
84,305,293 \pm 3.10 \\
2,122,511 \pm 9.18 \\
2,581,568 \pm 3.64 \\
57,571,093 \pm 4.25 \\
8,124,548 \pm 5.31 \\
10,570,259 \pm 8.41 \\
183,348,055^{\mathrm{a}} \pm 4.70\end{array}$ & $\begin{array}{l}\text { n.d. } \\
343,767 \pm 9.82 \\
\text { n.d. } \\
\text { n.d. } \\
2,162,994 \pm 3.06 \\
2,395,646 \pm 8.38 \\
882,129 \pm 6.20 \\
10,704,016 \pm 2.91 \\
\text { n.d. } \\
\text { n.d. } \\
\text { n.d. } \\
\text { n.d. } \\
\text { n.d. } \\
16,488,552^{\text {b }} \pm 6.07\end{array}$ & $\begin{array}{l}\text { n.d. } \\
188,176 \pm 1.21 \\
104,640 \pm 5.27 \\
\text { n.d. } \\
2,630,130 \pm 2.74 \\
3,080,865 \pm 4.07 \\
\text { n.d. } \\
15,651,220 \pm 2.42 \\
\text { n.d. } \\
\text { n.d. } \\
428,918 \pm 2.36 \\
\text { n.d. } \\
\text { n.d. } \\
22,083,949^{\text {b }} \pm 3.01\end{array}$ & $\begin{array}{l}\text { n.d. } \\
3,632,868 \pm 1.24 \\
701,503 \pm 7.23 \\
\text { n.d. } \\
16,271,851 \pm 1.56 \\
17,513,071 \pm 1.08 \\
7,742,849 \pm 9.56 \\
49,957,768 \pm 1.03 \\
\text { n.d. } \\
1,965,180 \pm 4.73 \\
5,065,830 \pm 8.36 \\
\text { n.d. } \\
2,189,229 \pm 3.93 \\
105,632,625^{a} \pm 4.30\end{array}$ \\
\hline $\begin{array}{l}\text { Alkanes } \\
\text { Decane } \\
\text { Total alkanes }\end{array}$ & 999.7 & $1000^{c}$ & $\begin{array}{l}5,357,674 \pm 3.53 \\
5,357,674 \pm 3.53\end{array}$ & $\begin{array}{l}\text { n.d. } \\
\text { n.d. }\end{array}$ & $\begin{array}{l}1,448,906 \pm 5.98 \\
1,448,906 \pm 5.98\end{array}$ & $\begin{array}{l}\text { n.d. } \\
\text { n.d. }\end{array}$ & $\begin{array}{l}\text { n.d. } \\
\text { n.d. }\end{array}$ \\
\hline $\begin{array}{l}\text { Alkenes } \\
\text { 1-Pentene }{ }^{t} \\
\text { 2-Pentene }{ }^{t} \\
\text { 2,3-Dimethyl-1-butene }{ }^{t} \\
\text { 4-Isothiocyanato-1-butene } \\
\text { Total alkenes }\end{array}$ & $\begin{array}{r}<600 \\
<600 \\
743.2 \\
991.8\end{array}$ & $\begin{array}{l}478^{\mathrm{e}} \\
510^{\mathrm{e}} \\
- \\
982^{\mathrm{e}}\end{array}$ & $\begin{array}{l}\text { n.d. } \\
\text { n.d. } \\
\text { n.d. } \\
\text { n.d. } \\
\text { n.d. }\end{array}$ & $\begin{array}{l}63,841 \pm 9.68 \\
512,829 \pm 4.93 \\
560,165 \pm 9.65 \\
4,486,553 \pm 3.91 \\
5,623,388 \pm 7.04\end{array}$ & $\begin{array}{l}\text { n.d. } \\
\text { n.d. } \\
\text { n.d. } \\
\text { n.d. } \\
\text { n.d. }\end{array}$ & $\begin{array}{l}\text { n.d. } \\
\text { n.d. } \\
\text { n.d. } \\
\text { n.d. } \\
\text { n.d. }\end{array}$ & $\begin{array}{l}\text { n.d. } \\
\text { n.d. } \\
\text { n.d. } \\
\text { n.d. } \\
\text { n.d. }\end{array}$ \\
\hline $\begin{array}{l}\text { Esters } \\
\text { Acetic acid methyl ester } \\
\text { Acetic acid ethyl ester } \\
\text { 2-Hydroxypropanoic acid methyl ester } \\
\text { 2-Methylpropanoic acid ethyl ester } \\
\text { 2-Methylbutanoic acid ethyl ester } \\
\text { 3-Methylbutanoic acid ethyl ester } \\
\text { Total esters }\end{array}$ & $\begin{array}{r}<600 \\
618.6 \\
742.1 \\
761.3 \\
850.7 \\
853.2\end{array}$ & $\begin{array}{l}522^{\mathrm{e}} \\
612^{\mathrm{c}} \\
- \\
756^{\mathrm{c}} \\
848^{\mathrm{c}} \\
852^{\mathrm{c}}\end{array}$ & $\begin{array}{l}\text { n.d. } \\
789,953 \pm 10.8 \\
\text { n.d. } \\
\text { n.d. } \\
\text { n.d. } \\
455,969 \pm 7.76 \\
1,245,922 \mathrm{a} \pm 9.28\end{array}$ & $\begin{array}{l}\text { n.d. } \\
1,069,536 \pm 4.73 \\
\text { n.d. } \\
\text { n.d. } \\
\text { n.d. } \\
\text { n.d. } \\
1,069,536 a \pm 4.73\end{array}$ & $\begin{array}{l}\text { n.d. } \\
789,123 \pm 8.27 \\
\text { n.d. } \\
\text { n.d. } \\
\text { n.d. } \\
\text { n.d. } \\
\text { 789,123a } \pm 8.27\end{array}$ & $\begin{array}{l}\text { n.d. } \\
1,109,238 \pm 4.82 \\
\text { n.d. } \\
423,159 \pm 6.07 \\
2,700,542 \pm 0.67 \\
812,594 \pm 9.52 \\
5,045,535 \pm 7.77\end{array}$ & $\begin{array}{l}773,312 \pm 5.16 \\
\text { n.d. } \\
3,057,807 \pm 1.80 \\
\text { n.d. } \\
\text { n.d. } \\
\text { n.d. } \\
\text { 3,831,119 } \pm 3.48\end{array}$ \\
\hline $\begin{array}{l}\text { Furans } \\
\text { 2-Methyl furan } \\
\text { 2-Ethyl furan } \\
\text { 2-Pentyl furan } \\
\text { Total furans }\end{array}$ & $\begin{array}{l}615.4 \\
706.0 \\
995.8\end{array}$ & $\begin{array}{l}605^{\mathrm{e}} \\
702^{\mathrm{C}} \\
992^{\mathrm{C}}\end{array}$ & $\begin{array}{l}499,667 \pm 5.21 \\
3,314,082 \pm 6.14 \\
\text { n.d. } \\
3,813,749^{a} \pm 5.68\end{array}$ & $\begin{array}{l}\text { n.d. } \\
2,112,721 \pm 5.05 \\
5,403,181 \pm 7.55 \\
7,515,902 \pm 6.30\end{array}$ & $\begin{array}{l}\text { n.d. } \\
\text { n.d. } \\
3,288,319 \pm 4.37 \\
3,288,319^{\mathrm{a}} \pm 4.37\end{array}$ & $\begin{array}{l}746,960 \pm 6.25 \\
905,270 \pm 1.21 \\
\text { n.d. } \\
1,652,230 \pm 3.73\end{array}$ & $\begin{array}{l}\text { n.d. } \\
\text { n.d. } \\
\text { n.d. } \\
\text { n.d. }\end{array}$ \\
\hline $\begin{array}{l}\text { Pyrazines } \\
\text { Methyl pyrazine } \\
\text { 2,5-Dimethyl pyrazine } \\
\text { Ethyl pyrazine }^{t} \\
\text { 2,3-Dimethyl pyrazine } \\
\text { 2-Ethyl-3-methyl pyrazine } \\
\text { 3-Ethyl-2,5-dimethyl pyrazine } \\
\text { 2-Allyl-3-methyl pyrazine } \\
\text { Total pyrazines }\end{array}$ & $\begin{array}{r}827.6 \\
915.4 \\
921.9 \\
925.9 \\
1008.3 \\
1087.5 \\
1111.1\end{array}$ & $\begin{array}{l}825^{c} \\
914^{c} \\
907^{d} \\
922^{c} \\
1003^{c} \\
1082^{d}\end{array}$ & $\begin{array}{l}\text { n.d. } \\
\text { n.d. } \\
\text { n.d. } \\
\text { n.d. } \\
\text { n.d. } \\
\text { n.d. } \\
\text { n.d. } \\
\text { n.d. }\end{array}$ & $\begin{array}{l}\text { n.d. } \\
\text { n.d. } \\
\text { n.d. } \\
\text { n.d. } \\
\text { n.d. } \\
\text { n.d. } \\
\text { n.d. } \\
\text { n.d. }\end{array}$ & $\begin{array}{l}\text { n.d. } \\
\text { n.d. } \\
\text { n.d. } \\
\text { n.d. } \\
\text { n.d. } \\
\text { n.d. } \\
\text { n.d. } \\
\text { n.d. }\end{array}$ & $\begin{array}{l}\text { n.d. } \\
\text { n.d. } \\
\text { n.d. } \\
\text { n.d. } \\
\text { n.d. } \\
\text { n.d. } \\
\text { n.d. } \\
\text { n.d. }\end{array}$ & $\begin{array}{l}11,122,315 \pm 3.07 \\
24,056,854 \pm 2.33 \\
2,817,370 \pm 0.83 \\
2,796,981 \pm 2.13 \\
12,852,725 \pm 4.51 \\
6,005,454 \pm 4.16 \\
1,360,717 \pm 4.22 \\
61,012,416 \pm 3.04\end{array}$ \\
\hline $\begin{array}{l}\text { Sulphur compounds } \\
\text { Dimethyl sulphide }^{t} \\
\text { Total sulphur compounds }\end{array}$ & $<600$ & $505^{\mathrm{d}}$ & $\begin{array}{l}830,920 \pm 13.9 \\
830,920 \pm 13.9\end{array}$ & $\begin{array}{l}\text { n.d. } \\
\text { n.d. }\end{array}$ & $\begin{array}{l}205,210 \pm 8.00 \\
205,210 \pm 8.00\end{array}$ & $\begin{array}{l}483,944 \pm 8.51 \\
483,944 \pm 8.51\end{array}$ & $\begin{array}{l}\text { n.d. } \\
\text { n.d. }\end{array}$ \\
\hline
\end{tabular}


Table 2 (continued)

\begin{tabular}{|c|c|c|c|c|c|c|c|}
\hline $\begin{array}{l}\text { Volatiles/samples } \\
\text { [peak area counts] }\end{array}$ & $\begin{array}{l}\mathrm{RI}_{\text {exp. }} \\
\text { [HP5] }\end{array}$ & $\begin{array}{l}\mathrm{RI}_{\mathrm{ref}} \\
{[\mathrm{HP5}]}\end{array}$ & $\begin{array}{l}\text { Flax seed } \\
\text { oil } \pm \text { RSD (\%) }\end{array}$ & $\begin{array}{l}\text { Rapeseed } \\
\text { oil } \pm \text { RSD (\%) }\end{array}$ & $\begin{array}{l}\text { Sesame seed } \\
\text { oil } \pm \text { RSD (\%) }\end{array}$ & $\begin{array}{l}\text { Sunflower seed } \\
\text { oil } \pm \text { RSD }(\%)\end{array}$ & $\begin{array}{l}\text { Pumpkin seed } \\
\text { oil } \pm \text { RSD (\%) }\end{array}$ \\
\hline \multicolumn{8}{|l|}{ Terpenes } \\
\hline \multicolumn{8}{|l|}{ Monoterpenes } \\
\hline$\alpha$-thujene $\mathrm{t}^{\mathrm{t}}$ & 937.1 & $938^{d}$ & $2,444,162 \pm 6.49$ & n.d. & n.d. & $115,327,200 \pm 8.98$ & $72,992,793 \pm 2.58$ \\
\hline$\alpha$-pinene & 950.3 & $933^{c}$ & $68,857,770 \pm 3.42$ & $12,443,185 \pm 4.09$ & $3,953,429 \pm 1.82$ & $1,396,221,468 \pm 0.94$ & $1,121,153254 \pm 0.57$ \\
\hline$\alpha$-fenchene ${ }^{t}$ & 963.5 & $951^{\mathrm{g}}$ & n.d. & n.d. & n.d. & $5,546,981 \pm 6.60$ & $2,478,339 \pm 5.21$ \\
\hline Camphene & 966.1 & $947^{c}$ & $2,600,534 \pm 6.23$ & $797,405 \pm 3.91$ & n.d. & $61,403,919 \pm 4.93$ & $39,074,552 \pm 1.45$ \\
\hline Verbenene ${ }^{t}$ & 970.1 & $972^{\mathrm{g}}$ & $1,365,519 \pm 10.0$ & $721,398 \pm 6.69$ & n.d. & $28,926,964 \pm 6.94$ & $31,293,751 \pm 8.02$ \\
\hline Sabinene $e^{t}$ & 986.5 & $972^{\mathrm{d}}$ & n.d. & n.d. & n.d. & $51,563673 \pm 5.59$ & $54,503,556 \pm 8.81$ \\
\hline 2- $\beta$-pinene & 994.5 & $976^{c}$ & $6,418,929 \pm 7.34$ & $2,490,579 \pm 7.14$ & n.d. & $74,220,323 \pm 1.74$ & $62,249,712 \pm 0.75$ \\
\hline$\alpha$-phellandrene ${ }^{t}$ & 1017.6 & $1007^{d}$ & $826,826 \pm 7.61$ & n.d. & $558900 \pm 6.87$ & $24,014,846 \pm 4.19$ & $16,572,851 \pm 1.86$ \\
\hline 3-Carene & 1024.7 & $1010^{c}$ & $3,510,435 \pm 7.83$ & n.d. & n.d. & n.d. & n.d. \\
\hline$\alpha$-terpinene & 1029.7 & $1016^{\mathrm{c}}$ & $1,160,987 \pm 11.8$ & $520,587 \pm 4.82$ & $324,206 \pm 6.95$ & $69,980,142 \pm 7.21$ & $50,415,755 \pm 2.35$ \\
\hline$\beta$-ocimene & 1039.7 & $1038^{c}$ & n.d. & n.d. & $8,061,835 \pm 6.16$ & n.d. & n.d. \\
\hline DL-Limonene & 1043.3 & $1028^{c}$ & $4,078,739 \pm 7.92$ & $4,416,719 \pm 6.01$ & $347,845 \pm 5.73$ & $64,266,826 \pm 5.69$ & $37,883,788 \pm 1.01$ \\
\hline$\beta$-phellandrene ${ }^{t}$ & 1046.8 & $1053^{d}$ & $996,213 \pm 10.7$ & n.d. & n.d. & $17,873,381 \pm 5.22$ & $11,261,708 \pm 2.48$ \\
\hline 1,8-Cineole & 1049.0 & $1031^{c}$ & $1,644,871 \pm 10.5$ & $1,064,745 \pm 5.50$ & n.d. & $2,427,452 \pm 2.39$ & $3,090,755 \pm 1.81$ \\
\hline o-Cymene & 1053.2 & $1020^{\mathrm{g}}$ & n.d. & n.d. & n.d. & $2,373,519 \pm 5.48$ & $2,440,141 \pm 0.62$ \\
\hline p-Cymene & 1033.3 & $1024^{\mathrm{c}}$ & $282,430 \pm 8.63$ & $1,993,462 \pm 4.52$ & $488,558 \pm 6.01$ & $80,410,702 \pm 7.34$ & $430,526 \pm 3.91$ \\
\hline$\gamma$-terpinene & 1071.1 & $1059^{c}$ & $4,708,773 \pm 11.34$ & $1,373,759 \pm 4.05$ & n.d. & $99,326,449 \pm 8.27$ & $50,415,755 \pm 2.35$ \\
\hline Limonene & 1082.5 & $1031^{g}$ & n.d. & n.d. & n.d. & $1,694,795 \pm 4.41$ & n.d. \\
\hline$\alpha$-terpinolene & 1102.7 & $1089^{c}$ & $1,583,457 \pm 3.77$ & n.d. & n.d. & $51,567,053 \pm 6.58$ & $30,169,802 \pm 0.81$ \\
\hline$\alpha$-campholenal ${ }^{\mathrm{t}}$ & 1145.6 & $1132^{\mathrm{e}}$ & $625,882 \pm 9.86$ & n.d. & n.d. & $36,718,739 \pm 3.14$ & $26,006,814 \pm 3.51$ \\
\hline Trans-pinocarveol $^{t}$ & 1166.2 & $1141^{\mathrm{g}}$ & n.d. & n.d. & n.d. & $12,673,019 \pm 4.13$ & $16,054,652 \pm 4.91$ \\
\hline$\alpha$-phellandren-8-ol ${ }^{\mathrm{t}}$ & 1171.6 & $1166^{\mathrm{e}}$ & n.d. & n.d. & n.d. & $1,155,942 \pm 8.17$ & n.d. \\
\hline Borneol $^{t}$ & 1193.0 & $1162^{\mathrm{d}}$ & n.d. & n.d. & n.d. & $2,609,803 \pm 6.11$ & $2,250,445 \pm 1.12$ \\
\hline 4-Terpineol & 1199.9 & $1192^{c}$ & n.d. & n.d. & n.d. & $4,068,391 \pm 9.59$ & $1,865,589 \pm 8.09$ \\
\hline 3-Pinanone ${ }^{t}$ & 1203.2 & $1173^{f}$ & n.d. & n.d. & n.d. & $2,707,501 \pm 3.68$ & $1,542,634 \pm 6.55$ \\
\hline 2-Pinen-10-ol ${ }^{t}$ & 1220.4 & $1204^{\mathrm{e}}$ & n.d. & n.d. & n.d. & $3,403,019 \pm 3.28$ & $2,972,675 \pm 4.09$ \\
\hline Myrtenal $^{t}$ & 1225.3 & $1233^{d}$ & n.d. & n.d. & n.d. & $3,526,538 \pm 1.38$ & $3,610,065 \pm 7.11$ \\
\hline Verbenone $^{t}$ & 1238.3 & $1204^{\mathrm{g}}$ & n.d. & n.d. & n.d. & $16,708,623 \pm 5.40$ & $16,199,201 \pm 2.33$ \\
\hline$\alpha$-cubebene ${ }^{t}$ & 1378.6 & $1345^{\mathrm{d}}$ & n.d. & n.d. & n.d. & $57,999 \pm 7.74$ & $222,202 \pm 8.90$ \\
\hline Camphor & 1173.9 & $1146^{c}$ & $450579 \pm 9.97$ & n.d. & n.d. & $895,118 \pm 5.87$ & $1,060,171 \pm 9.41$ \\
\hline \multicolumn{8}{|l|}{ Sesquiterpenes } \\
\hline$\alpha$-copaene & 1408.8 & $1381^{\mathrm{c}}$ & n.d. & n.d. & n.d. & $909,068 \pm 8.06$ & $497,409 \pm 5.03$ \\
\hline$\beta$-elemene ${ }^{t}$ & 1422.7 & $1393^{d}$ & n.d. & n.d. & n.d. & $418,277 \pm 6.18$ & $456,148 \pm 6.97$ \\
\hline$\beta$-bourbonene ${ }^{t}$ & 1426.3 & $1417^{d}$ & n.d. & n.d. & n.d. & $434,948 \pm 4.54$ & $307,049 \pm 3.16$ \\
\hline$\beta$-selinene $e^{t}$ & 1458.6 & $1436^{\mathrm{d}}$ & n.d. & n.d. & n.d. & $157,558 \pm 4.77$ & $141,954 \pm 7.34$ \\
\hline 2-Norpinene $\mathrm{e}^{\mathrm{t}}$ & 1463.2 & $1430^{e}$ & n.d. & n.d. & $926,500 \pm 6.69$ & $320,465 \pm 4.98$ & $401,848 \pm 6.56$ \\
\hline Aristolen $^{t}$ & 1467.8 & $1428^{\mathrm{e}}$ & n.d. & n.d. & n.d. & $1,684,564 \pm 7.25$ & $1,367,821 \pm 5.79$ \\
\hline$\gamma$-cadinene ${ }^{t}$ & 1473.3 & $1543^{d}$ & n.d. & n.d. & n.d. & $941,170 \pm 7.39$ & $879,800 \pm 4.73$ \\
\hline Calarene $^{t}$ & 1481.6 & $1444^{\mathrm{f}}$ & n.d. & n.d. & n.d. & $35,461,306 \pm 7.16$ & $29,287,327 \pm 8.80$ \\
\hline$\alpha$-amorphene ${ }^{t}$ & 1513.7 & $1506^{\mathrm{g}}$ & n.d. & n.d. & n.d. & $399,534 \pm 0.80$ & $348,410 \pm 8.03$ \\
\hline$\beta$-bisabolene $e^{t}$ & 1534.3 & $1498^{\mathrm{d}}$ & n.d. & n.d. & n.d. & $1,155,793 \pm 6.12$ & $1,321,563 \pm 2.00$ \\
\hline$\delta$-cadinene $\mathrm{e}^{\mathrm{t}}$ & 1558.9 & $1519^{d}$ & n.d. & n.d. & n.d. & $671,090 \pm 8.89$ & $526,508 \pm 4.83$ \\
\hline Total terpenes & & & $101,556,106^{a} \pm 8.23$ & $25,821,839^{a} \pm 5.19$ & $14,661,273^{\mathrm{a}} \pm 5.75$ & $2,270,697620 \pm 5.57$ & $1,693,747,323 \pm 4.41$ \\
\hline \multicolumn{8}{|l|}{ Other compounds } \\
\hline Pyridine $^{t}$ & 751.4 & $753^{e}$ & n.d. & n.d. & n.d. & n.d. & $1,779,272 \pm 10.7$ \\
\hline Not identified & 843.4 & - & n.d. & n.d. & n.d. & $2,060,348 \pm 2.80$ & $2,558,074 \pm 5.19$ \\
\hline Ethylbenzene $^{t}$ & 871.5 & $871^{\mathrm{e}}$ & $4,115,603 \pm 4.28$ & 0 & $2,444,433 \pm 4.08$ & $779,326 \pm 5.39$ & $1,233,348 \pm 5.27$ \\
\hline Butyrolactone $^{t}$ & 919.3 & $915^{\mathrm{e}}$ & $4,207,555 \pm 6.43$ & $4,981,735 \pm 5.05$ & $2,385,299 \pm 2.54$ & $3,227,877 \pm 8.52$ & $13,352,876 \pm 2.72$ \\
\hline 1,5,8-p-Menthatriene ${ }^{t}$ & 1005.4 & - & n.d. & n.d. & n.d. & $7,866,858 \pm 6.88$ & $8,277,121 \pm 2.25$ \\
\hline 1,2,4-Trimethyl benzene ${ }^{t}$ & 1006.9 & $1000^{\mathrm{e}}$ & $2,481,381 \pm 11.0$ & n.d. & $1,356,391 \pm 5.93$ & n.d. & n.d. \\
\hline 1,3,8-para-Menthatriene ${ }^{t}$ & 1114.2 & $1113^{e}$ & n.d. & n.d. & n.d. & $1,053,886 \pm 1.86$ & $1,406,212 \pm 7.04$ \\
\hline Total other compounds & & & $10,804,539^{\mathrm{a}, \mathrm{b}} \pm 7.24$ & $40,981,735 \pm 4.79$ & $6,186,123^{\mathrm{b}} \pm 4.64$ & $14,208,969^{\mathrm{a}} \pm 5.46$ & $28,606,903 \pm 5.31$ \\
\hline Total volatile compounds & & & $214,955,261^{\mathrm{a}} \pm 8.40$ & $280,374,460^{\mathrm{a}} \pm 5.04$ & $68,311,349 \pm 6.42$ & $2,331,899,274 \pm 6.15$ & $1,967,137,860 \pm 4.72$ \\
\hline
\end{tabular}

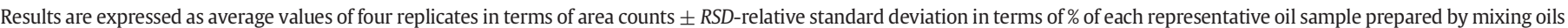
from three lots prepared at same way; $\mathrm{n}=4$.

Same superscripts $\left({ }^{\mathrm{a}, \mathrm{b}}\right)$ in the same line indicate values that are not statistically different from one another $(p>0.05)$.

$\mathrm{RI}-$ retention index.

$\mathrm{RI}_{\text {exp. }} \mathrm{RI}$ as determined in the experiments.

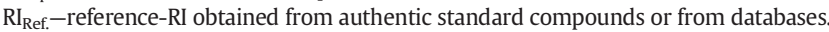

t-Tentatively identified, tentative identification is based on the mass spectra and RIs obtained from RI databases.

c-RI obtained from authentic reference compounds.

d_RI obtained from http://www.flavornet.org.

e_RI obtained from http://webbook.nist.gov/.

f-RI obtained from literature (da Silva et al., 2015).

g_RI obtained from http://www.pherobase.com. 
in rapeseed oil and pumpkin seed oil (5.6\% and 2.01\% of the total aldehydes, respectively), while octanal was present only in rapeseed oil. In fact, hexanal arises from linoleic acid while octanal and nonanal, which are usually present in very low amounts in oils, are oleic acid derivatives (Haiyan et al., 2007). Strecker aldehydes, such as 2- and 3methyl butanal were present in considerable amounts in all oil samples, ranging from $1.34 \%$ to $46 \%$ and $1.99 \%$ to $14.9 \%$, respectively.

\subsubsection{Alkanes, alkenes}

Small amounts of alkanes and alkenes are usually present in oils. In our study, decane was the only alkane detected in flax seed and sesame seed oils. With regards to alkenes, 1-pentene, 2-pentene, 2,3-dimethyl1-butene and 4-isothiocyanato-1-butene were detected only in rapeseed oil, presenting $22 \%$ of the overall volatiles in the sample.

\subsubsection{Esters}

Esters are another group of volatile compounds that may influence the flavour properties of oils. In this study, six esters were identified in the oils, including acetic acid methyl ester, acetic acid ethyl ester, 2hydroxypropanoic acid methyl ester, 2-methylpropanoic acid ethyl ester, 2-methylbutanoic acid ethyl ester and 3-methylbutanoic acid ethyl ester. Acetic acid methyl ester, 2-hydroxypropanoic acid methyl ester and 2-methyl butanoic acid ethyl ester were detected only in the pumpkin seed oil, while rapeseed and sesame oils contained only one compound out of this group, which is acetic acid ethyl ester as a reaction product of ethanol and acetic acid, that are both present in both oils. Comparing the different oils, pumpkin seed oil presented the highest relative amount of volatile esters, followed by sunflower seed oil $(p<$ 0.05 ), whereas no significant difference was observed in the total relative amount of esters between rapeseed, flax seed and sesame seed oils $(p>0.05)$. Short chain esters of methyl branched acids are supposed to be degradation products of the corresponding amino acids valine, leucine or isoleucine formed either during the amino acid pathway in course the maturation of seeds or via Strecker degradation (Parker, 2015; Reineccius, 2006). The enzymatically catalysed and/or chemical oxidation to the corresponding acids and subsequent esterification to the corresponding ethyl ester is likely to occur in the oils.

\subsubsection{Furans}

Alkylated furans were reported previously in various nuts and oilseeds (Siegmund \& Murkovic, 2004). They are products of either lipid autoxidation or carbohydrate degradation (Frankel, 1982; Maga, 1979). As a consequence, the formation of alkylated furans is expected in the investigated oils. Thus, within this family three compounds were detected in the oils: 2-methyl furan, 2-ethyl furan and 2-pentyl furan. In terms of variety, flax seed oil and sunflower seed oil presented the highest proportion of 2-ethyl furan ( $86.9 \%$ and $54.8 \%$, respectively) followed by 2 -methyl furan $(13.1 \%$ in flax seed and $45.2 \%$ in sunflower seed oil). 2-Pentyl furan was detected only in sesame seed oil and rapeseed oil. Comparing the total relative amount of furans (Table 2), the rapeseed oil showed the highest relative amount, followed by flax seed, sesame seed and sunflower seed oil $(p<0.05)$, while furans were not detected in the pumpkin seed oil.

\subsubsection{Pyrazines}

Pyrazines are heterocyclic compounds formed during the roasting of the seeds in course of the Maillard reaction. They are responsible for the toasted and roasted flavours in various products (Lee \& Shibamoto, 2002; Parker, 2015). In this study, pyrazines were not detected in flax seed oil, sesame seed oil, sunflower seed oil and rapeseed oil, which was in accordance with literature (Haiyan et al., 2007), as these oils were produced with minimal heating of the seeds. In contrast to sesame seed oil from other geographical regions, where the sesame seeds are frequently roasted before pressing resulting in the formation of pyrazines as typical Maillard reaction products (Schieberle, 1996), the Macedonian sesame seeds were not roasted prior to the pressing procedure. Only pumpkin seed oil contained pyrazine derivatives. Thus, seven alkylated pyrazines were identified in the pumpkin seed oil including methyl pyrazine, ethyl pyrazine, 2,3-dimethyl pyrazine, 2,5-dimethyl pyrazine, 2-ethyl-3-methyl pyrazine, 2-ethyl-2,5-dimethyl pyrazine and 2-allyl-3-methyl pyrazine, which is in accordance to previous studies (Buchbauer, Boucek \& Nikiforov, 1998; Nikiforov, Knapp, Buchbauer \& Jirovetz, 1996; Poehlmann \& Schieberle, 2013; Siegmund \& Murkovic, 2004). Among them, 2,5-dimethyl pyrazine was the dominant one present in $39.4 \%$ of the total pyrazines, followed by 2-ethyl-3-methyl pyrazine (21.1\% of the total pyrazines) and methyl pyrazine (18.2\% of the total pyrazines). The total percentage of pyrazines in the pumpkin seed oil was $21.2 \%$ of the overall volatile compounds. In fact, pyrazine derivatives are responsible for the typical flavour of pumpkin seed oils described as nutty, roasty, spicy, 'warm', slightly green and fatty (Siegmund \& Murkovic, 2004; Wenzl, Prettner, Schweiger \& Wagner, 2002). Thermal processing of the seeds at temperatures of $100-130{ }^{\circ} \mathrm{C}$ prior to the pressing of the oil is necessary for the formation of these compounds (Siegmund \& Murkovic, 2004). The flavour compounds with the highest sensory impact connected with the impression of a 'roasty' aroma of Styrian pumpkin seed oil were reported for 2-ethyl-3,5-dimethylpyrazine, 2,3-diethyl-5-methylpyrazine and 3-ethyl-2,5-dimethylpyrazine (Matsui, Guth \& Grosch, 1997).

\subsubsection{Sulphur compounds}

Only one sulphur compound, dimethyl sulphide, was detected in flax seed, sesame seed and sunflower seed oils. This compound contributes cooked cabbage, corn and seafood flavour when present in concentrations above its sensory threshold (Buttery, Teranishi, Ling \& Turnbough, 1990; Quian, Fan \& Mahattanatawee, 2011). Sulphur compounds in oils can arise from the breakdown of glucosinolates present in the seeds or from methionine degradation followed by $\mathrm{H}_{2} \mathrm{~S}$ formation (Ballance, 1961). In fact, sulphur in oils could be present in a number of forms which may have different effects on the flavour of the final oil. Rutkowski, Gwizad, and Krygier (1982) confirmed that sulphur compounds in rapeseed oil occur in volatile, thermo labile and nonvolatile forms. Their relative proportions vary on the particular stage of the refining process. Even present in trace quantities, the sulphur compounds attract the attention of scientists because they inhibit oil hardening processes and impact characteristics odours to the oils (Rutkowski et al., 1982). We suppose that the sensitivity of the used HS-SPME GC-MS was not high enough for the detection of further sulphur compounds.

\subsubsection{Terpenes}

Terpenes are widespread compounds in nature, mainly present in plants as constituents of the essential oils. Due to the molecular weight and the corresponding volatility, mainly mono- (C10) and sesquiterpenes (C15) as hydrocarbons or as oxygenated compounds are considered to be important for the flavour of food. Interestingly, rather little information can be found in literature about the occurrence of mono- and sesquiterpenes in edible vegetable oils, with the exception of olive oil (Cecchi \& Alfei, 2013; Vichi, Pizzale, Conte, Buxaderas \& López-Tamames, 2003; Zunin, Boggia, Savadeo \& Evangelisti, 2005). In (extra) virgin olive oil, a large number of mono- and sesquiterpenes have been identified. Their impact on the sensory properties of the oils is generally estimated to be low, mainly due to their rather low concentrations in combination with their mostly rather high odour thresholds. However, there are several attempts mainly from Italy to use the terpene composition as a suitable marker of the geographic origin and genotype (Vichi et al., 2003; Zunin et al., 2005). In our study 41 terpenes, including monoterpenes (30 compounds) and sesquiterpenes (11 compounds) were identified in the oils, mainly present in sunflower seed oil which showed the highest total relative amount of the total terpenes, followed by pumpkin seed oil. In general, monoterpenes were present in a higher relative amount compared to the sesquiterpenes. Sesquiterpenes were detected in sunflower seed and pumpkin seed oil, and only 

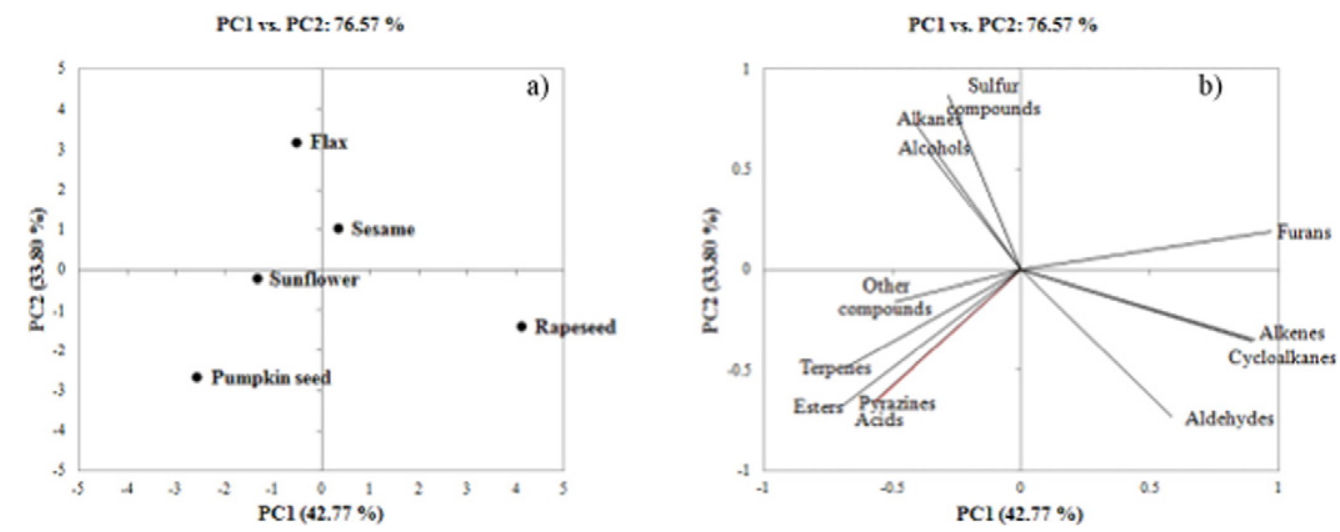

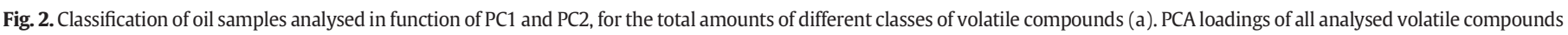
in the investigated oil samples (b).

one sesquiterpene, 2-norpinene, was found in sesame seed oil. In general, sunflower seed and pumpkin seed oils showed significantly higher relative amounts of total terpenes $(p>0.05)$ compared to flax seed, rapeseed and sesame seed oils. In terms of variety, $\alpha$-pinene was the main terpene in flax seed, representing $68.2 \%$ of the total terpenes, followed by pumpkin seed oil (66.2\% of the total terpenes), sunflower seed ( $63.7 \%$ of the total terpenes) and rapeseed oil (55.2\% of total terpenes), while $\beta$-ocimene was dominant in sesame seed oil $(56.9 \%$ of total terpenes). In addition, flax seed oil contained considerable amounts of $2-\beta$-pinene ( $6.35 \%$ of the total terpenes), $\gamma$-terpinene (4.66\% of the total terpenes) and dl-limonene $(4.04 \%$ of the total terpenes), while the monoterpenes dl-limonene and 2- $\beta$-pinene were found in high relative amounts in rapeseed oil, presenting $18.5 \%$ and $10.5 \%$ of the total terpenes in the oil. In literature, most of the terpenoid compounds were reported in extra virgin olive oil. Interestingly, the number of terpenoid compounds reported in sunflower seed oil is limited (Bendini et al., 2011; Hernández, 2013). Sunflower seed oil is usually brought onto the market as refined oil - mono- and sesquiterpenes seem to be removed from the oil during the refining procedure (Eckert, Zeman \& Moser, 1973). In oils from roasted oil seeds, like the traditional pumpkin or sesame seed oils, the number of reported terpenoid compounds is very low, which again is in contrast to our findings. The absence of the roasting process in case of the investigated sesame seed oil, or the rather mild roasting conditions that were applied during the roasting of the pumpkin seeds, respectively, might be the reason for the presence of high numbers of mono- and sesquiterpenes. However, the findings on the terpenes in the Macedonian oils need further investigations before drawing conclusions on their sensory impact of the oils.

\subsubsection{Other compounds}

Among the other volatile compounds found in oils, eight compounds were classified in this group (Table 2). $\gamma$-butyrolactone (oxolan-2-one) was the predominant compound in all oils, with the exception of sunflower seed oil.

\subsubsection{PCA}

Principal component analysis (PCA) was used to explore the contribution of different flavour classes on the clustering among the oils. Projection of the oils on the first two principal components (explained variability: 76.57\%) showed a clear separation of the oils (Fig. 2a). Sunflower seed and pumpkin seed oil were located in the negative part of PC1, flax seed oil in the upper negative part of PC1, while rapeseed and sesame seed oil were placed in the positive part of PC1. In fact, rapeseed oil was clearly separated from the other four oils.

PCA results of the variables (in terms of the total content of the different flavour compounds) used for the characterisation of the oil samples displayed into the first two principal components are presented in Fig. 2b. Terpenes, esters and pyrazines, that prevail in the negative part of the first principal component, are characteristic for sunflower seed and pumpkin seed oil, while dimethyl sulphide, alkanes and alcohols were characteristic for flax seed oil. Alkenes, esters and furans were dominant in the rapeseed oil, responsible for its separation.

\section{Conclusions}

Traditional Macedonian edible oils of five varieties, including sunflower seed, pumpkin seed, flax seed, rapeseed and sesame seed, were analysed with respect to their fatty acid composition and the volatile compounds. GC-FID after transesterification of the fatty acids was used for the analysis of the fatty acids and HS-SPME GC-MS for the analysis of the volatile compounds. The fatty acid profile of oils was in accordance to the official legislation. In total, $97 \mathrm{vol}-$ atile compounds were, for the first time described in the Macedonian edible oils. Regarding the variety, sunflower seed oil and pumpkin seed oil were found to be richest in terpenes and esters, presenting the highest average amount of total volatile compounds. The obtained results from the selected Macedonian edible oils provide important information for the Macedonian oil production which aim to develop brands for edible oils especially regarding seeds - such as pumpkin seed and sunflower seeds - that have traditionally been used as sources for edible oils in this region.

\section{Acknowledgement}

This work was supported by a grant from the CEEPUS, CII-HU0010-03-0809 Network, covering the study stay of Violeta IvanovaPetropulos at the Institute of Analytical Chemistry and Food Chemistry, Graz University of Technology, Graz, Austria, where the gas chromatographic analyses of oils were performed.

\section{References}

Ballance, P. E. (1961). Production of volatile compounds related to the flavour of foods from the Strecker degradation of DL-methionine. Journal of the Science of Food and Agriculture, 12, 532-536.

Ballesteros, E. Gallego, M. \& Valcárcel, M. (1993). Automatic method for on-line preparation of fatty acid methyl esters from olive oil and other types of oil prior to their gas chromatographic determination. Analytica Chimica Acta, 282, 581-588.

Bendini, A., Barbieri, S., Valli, E., Buchecker, K., Canavari, M., \& Toschi, T. G. (2011). Quality evaluation of cold pressed sunflower oils by sensory and chemical analysis. European Journal of Lipid Science and Technology, 113, 1375-1384.

Buchbauer, G., Boucek, B., \& Nikiforov, A. (1998). On the aroma of Austrian pumpkin seed oil: correlation of analytical data with olfactoric characteristics. Nutrition, 22, 246-249.

Buttery, R. G., Teranishi, R., Ling, L. C., \& Turnbough, J. G. (1990). Quantitative and sensory studies on tomato paste volatiles. Journal of Agricultural and Food Chemistry, 38, 336-340. 
Cao, J., X Zou, X. -G., Deng, L., Fan, Y. -W., Li, H., Li, J., et al. (2014). Analysis of nonpolar lipophilic aldehydes/ketones in oxidized edible oils using HPLC-QqQ-MS for the evaluation of their parent fatty acids. Food Research International, 64, 901-907.

Cecchi, T., \& Alfei, B. (2013). Volatile profiles of Italian monovarietal extra virgin olive oils via HS-SPME-GC-MS: newly identified compounds, flavors molecular markers, and terpenic profile. Food Chemistry, 141, 2025-2035.

Cert, A., Moreda, W., \& Perez-Camino, M. C. (2000). Chromatographic analysis of minor constituents in vegetable oils - review. Journal of Chromatography. A, 881, 131-148.

Choe, E., \& Min, D. B. (2006). Mechanisms and factors for edible oil oxidation. Comprehensive Reviews in Food Science and Food Safety, 5, 169-186.

da Silva, C. E. L., Minguzzi, S., da Silva, R. C. L., Matos, M. F. C., Tofoli, D., de Carvalho, J. E., et al. (2015). Chemical composition and cytotoxic activity of the root essential oil from Jatropha ribifolia (Pohl) Baill (Euphorbiaceae). Journal of the Brazilian Chemical Society, 26(2), 233-238.

De Koning, S., van der Meer, B., Alkema, G., Janssen, H. -G., \& Brinkman, U. A. Th. (2001). Automated determination of fatty acid methyl ester and cis/trans methyl ester composition of fats and oils. Journal of Chromatography. A, 922, 391-397.

Eckert, W. R., Zeman, A., \& Moser, R. (1973). Occurrence of terpene hydrocarbons in sunflower oil. Fette, Seifen, Anstrichmittel, 75(8), 475-478.

Feussner, I., \& Wasternak, C. (2002). The lipoxygenase pathway. Annual Review of Plant Biology, 53, 275-297.

Frankel, E. N. (1982). Volatile lipid oxidation products. Progress in Lipid Research, 22, 1-33.

Gliszczyńska-Świgło, A., Sikorska, E., Khmelinskii, I., \& Sikorski, M. (2007). Tocopherol content in edible plant oils. Polish Journal of Food E Nutrition Sciences, 57, 157-161.

Gromadzka, Ju., \& Wardencki, W. (2011). Trends in edible vegetable oils analysis. Part A. Determination of different components of edible oils - a review. Polish Journal of Food Nutrition Sciences, 61(1), 33-43.

Gulaboski, R., Mirceski, V., \& Mitrev, S. (2013). Development of a rapid and simple voltammetric method to determine total antioxidative capacity of edible oils. Food Chemistry, 138, 116-121.

Haiyan, Z., Bedgood, D. R., Jr., Bishop, A. G., Prenzler, P. D., \& Robards, K. (2007). Endogenous biophenol, fatty acid and volatile profiles of selected oils. Food Chemistry, 100, 1544-1551.

Hernández, P. B. N. (2013). Volatile aroma components of cold pressed virgin oils from several Venezuelan seed. Research and Reviews, Journal of Food and Dairy Technology, 1(2), 13-17.

Hu, W., Zhang, L., Li, P., Wang, X., Zhang, Q., Xu, B., et al. (2014). Characterization of volatile components in four vegetable oils by headspace two-dimensional comprehensive chromatography time-of-flight mass spectrometry. Talanta, 129, 629-635.

Jansen, F. J. H. M. (2015). Managing flavour changes during storage. In J. K. Parker, J. S. Elmore, \& L. Methven (Eds.), Flavour Development, Analysis and Perception in Food and Beverages (pp. 249-270). Cambridge: Woodhead Publishing.

Kalua, C. M., Allen, N. S., Bedgood, D. R., Jr., Bishop, A. G., Prenzler, P. D., \& Robards, K. (2007). Olive oil volatile compounds, flavour development and quality: a critical review. Food Chemistry, 100, 273-286.

Kostadinova, E., Alipieva, K., Stefova, M., Stafilov, T., Antonova, D., Evstatieva, Lj, et al. (2007). Chemical composition of the essential oils of three Micromeria species growing in Macedonia and Bulgaria. Macedonian Journal of Chemistry and Chemical Engineering, 26(1), 3-7.

Kostik, V., Memeti, S., \& Bauer, B. (2013). Fatty acid composition of edible oils and fats. Journal of Hygienic Engeneering \& Design, 4, 112-116.

Lee, K. G., \& Shibamoto, T. (2002). Toxicology and antixodant activities of non-enzymatic browning reaction products. Food Reviews International, 18, 151-175.

Ma, C., Ji, J., Tan, C., Chen, D., Luo, F., Wang, Y., et al. (2014). Headspace solid-phase microextraction coupled to gas chromatography for the analysis of aldehydes in edible oils. Talanta, 20, 94-99.

Maga, J. A. (1979). Furans in foods. CRC Critical Reviews in Food Science and Nutrition, $355-400$.

Matsui, T., Guth, H., \& Grosch, W. (1997). A comparative study of potent odorants in peanut, hazelnut, and pumpkin seed oils on the basis of aroma extract dilution analysis (AEDA) and gas chromatography-olfactometry of headspace samples (GCOH). FettLipid, 100, 51-56.

Murkovic, M., Hillebrand, A., Winkler, W. J., Leitner, E., \& Pfannhauser, W. (1996). Variability of fatty acid content in pumpkin seeds (Cucurbita pepo L.). European Food Research and Technology, 203, 216-219.
Murkovic, M., Piironen, V., Lampi, A. M., Kraushofer, T., \& Sontag, G. (2004). Changes in chemical composition of pumpkin seeds during the roasting process for production of pumpkin seed oil (part 1: non-volatile compounds). Food Chemistry, 84, 359-365.

Najdoska, M., Bogdanov, J., \& Zdravkovski, Z. (2010). TLC and GC-MS analyses of essential oil isolated from Macedonian Foeniculi fructus. Macedonian Pharmaceutical Bulletin, 56(1,2), 29-36.

Nikiforov, A., Knapp, M., Buchbauer, G., \& Jirovetz, L. (1996). Determination of the dominating odor components (character impact compounds) of Styrian pumpkin seed oil (in German). Nutrition, 20, 643-644.

Official Gazzete of the Republic of Macedonia, No. 127, October 15, 2015, pages 60-72 (http://www.slvesnik.com.mk/id-and-basic-information.nspx).

Parker, J. K. (2015). Thermal generation of aroma. In J. K. Parker, J. S. Elmore, \& L. Methven (Eds.), Flavour Development, Analysis and Perception in Food and Beverages (pp. 151-185). Cambridge: Woodhead Publishing.

Poehlmann, S., \& Schieberle, P. (2013). Characterization of the aroma signature of Styrian pumpkin seed oil (Cucurbita pepo subsp. pepo var. Styriaca) by molecular sensory science. Journal of Agricultural and Food Chemistry, 61, 2933-2942.

Quian, M., Fan, X., \& Mahattanatawee, K. (2011). Volatile Sulphur Compounds in Food. Washington DC: American Chemical Society (Chapter 1).

Reineccius, G. (2006). Flavour formation of fruits and vegetables. In G. Reineccius (Ed.) Flavour Chemistry and Technology (pp. 73-101). Boka Raton, USA: CRC Press.

Rutkowski, A., Gwizad, S., \& Krygier, K. (1982). Sulfur compounds affecting processing of rapeseed. Journal of the American Oil Chemists' Society, 59, 7-11.

Santos, J. E. R., Villarino, B. J., Zosa, A. R., \& Dayrit, F. M. (2011). Analysis of volatile organic compounds in virgin coconut oil and their sensory attibutes. The Philippine Journal of Science, 140(2), 161-171

Schieberle, P. (1996). Odour-active compounds in moderately roasted sesame. Food Chemistry, 55(2), 145-152.

Schuster, W., Zipse, W., \& Marquard, R. (1983). Influence of genotype and cultivation place on various ingredients of oil-gourd seeds (Cucurbita pepo L.). Fat Science Technology, 85(2), 56-64.

Siegmund, B., \& Murkovic, M. (2004). Changes in chemical composition of pumpkin seeds during the roasting process for production of pumpkin seed oil (part 2: volatile compounds). Food Chemistry, 84, 367-374.

Stefkov, G., Cvetkovikj, I., Karapandzova, M., \& Kulevanova, S. (2011). Essential oil composition of wild growing Sage from R. Macedonia. Macedonian Pharmaceutical Bulletin. 57(1,2), 71-76.

Tannenbaum, S. R. (1979). Nutritional and Safety Aspects of Food Processing. New York: Marcel Dekker, 98

Temime, S. B., Campeol, E., Cioni, P. L., Daoud, D., \& Zarrouk, M. (2006). Volatile compounds from Chétoui oil and variations induced by growing area. Food Chemistry, 99, 315-325.

Vichi, S., Pizzale, L., Conte, L. S., Buxaderas, S., \& López-Tamames, E. (2003). Solid-phase microextraction in the analysis of virgin olive oil volatile fraction: characterization of virgin olive oils from two distinct geographical areas of northern Italy. Journal of Agricultural and Food Chemistry, 51, 6572-6577.

Wenzl, T., Prettner, E., Schweiger, K., \& Wagner, F. S. (2002). An improved method to discover adulteration of Styrian pumpkin seed oil. Journal of Biochemical and Biophysical Methods, 53, 193-202.

Wilkes, J. G., Conte, E. D., Kim, Y., Holcomb, M., Sutherland, J. B., \& Miller, D. W. (2000). Sample preparation for the analysis of flavors and off-flavors in foods. Journal of Chromatography. A, 880, 3-33.

Zeb, A., \& Murkovic, M. (2010). Analysis of triacylglycerols in refined edible oils by isocratic HPLC-ESI-MS. European Journal of Lipid Science and Technology, 112, 844-861.

Zhang, L., Li, L., Sun, X., Wang, H., Xu, B., Wang, H., et al. (2014). Classification and adulteration detection of vegetable oils based on fatty acid profiles. Journal of Agricultural and Food Chemistry, 62, 8745-8751.

Zunin, P., Boggia, R., Savadeo, P., \& Evangelisti, F. (2005). Geographical traceability of West Liguria extravirgin olive oils by the analysis of volatile terpenoid hydrocarbons. Journal of Chromatography. A, 1089, 243-249. 